\title{
Database Generation for the Development of Village Information System (VIS)
}

\author{
Pradip Ashok Saymote, Ph.D \\ Assistant Professor \\ P. G. Dip. in Geoinformatics, \\ Department of Geography \\ Shivaji University, Kolhapur, India
}

\begin{abstract}
According to Mahatma Gandhiji village is a backbone of our nation. In planning and development process village should be at the centre. Village information system (VIS) is a micro level study which may helpful to planners, policy makers and administrators in planning and decision making process. It is seen that may planning gets fail due to insufficient and non availability of data.

Data is considered as raw material from which meaningful results and analysis can be carried out. Database is a group of organized records and files which are stored systematically and shared by different users. To generate an information system it requires lot of data and database integrated with GIS.

Comprehensive village level information system is a need of hour and in this system database generation is a prime task. Microsoft Access is a low cost, widely available relational database management system (RDBMS) used mainly by home and small business users. Therefore in this paper an attempt is made to highlight the process of database generation for the development of VIS using MS-Access.
\end{abstract}

\section{General Terms}

Data, Database

\section{Keywords}

Village Information System (VIS), MS-Access, Village Savali

\section{INTRODUCTION}

According to Mahatma Gandhiji village is a backbone of our nation hence village should be the centre of planning and development activity. Village information system is a micro level study which may helpful to planners, policy makers and administrators in the planning and decision making process. There are various attempts carried out on private as well as government level for the betterment of villages; in this process modern technologies playing vital role [1]. Geoinformatics is an emerging branch of science and technology has lot of potential to enrich rural lives and bring revolutionary changes by all manners.

In the development of Village Information System data and database plays a central role. Data refer to a collection of facts and figures, usually collected as the result of experience, observation, experiment, processes within a computer system or a set of premises. This may consist of numbers, words, images, etc. Decision makers and planners are handicapped today due to the lack of authentic, complete and up to date information [2].
A database can be explained as a set of logically related files organized to facilitate access by one or more applications programs, systematic storage and minimum data redundancy. A database management system (DBMS) is system software used to manage the organization, storage, access, security and integrity of data in a structured database [3]. In other words DBMS is a structured collection of records or data that is stored in a computer system is known as database. In development of VIS it requires lot of data and organized database (Geodatabase integrated with GIS) [4]. In GIS perspective data is of two types i.e. spatial and non-spatial. Non spatial data (also known as attribute data) which is a description about spatial features whereas; the data which is having its spatial location on earth surface i.e. spatial features or spatial data [5]. In the development of VIS both spatial and non spatial data are equally important. In this paper an attempt is made to highlight the process of database generation for the development of Village Information System using MSAccess.

\section{AIM \& OBJECTIVES}

The aim of this research is to generate a database for developing a Village Information System. Following are the related objectives:

1. To understand the database design required for Village Information System.

2. To generate the VIS database structure using MSAccess.

3. To check the compatibility and suitability of MSAccess for village level application.

\section{STUDY AREA}

The study region selected for the development of VIS is a village "Savali". This is a small village located in Miraj tahsil of Sangli district within coordinates of $16^{\circ} 46^{\prime} 28^{\prime \prime}$ to $16^{\circ} 53^{\prime}$ $45^{\prime}$ North Latitude and $74^{\circ} 31^{\prime} 08^{\prime \prime}$ to $74^{\circ} 40^{\prime}$ 51" East Longitudes and covers 536 hectors area. This village is $7 \mathrm{~km}$ 's from Sangli and $6 \mathrm{~km}$ 's from Miraj at triangular location near Maharashtra Industrial Development Corporation.

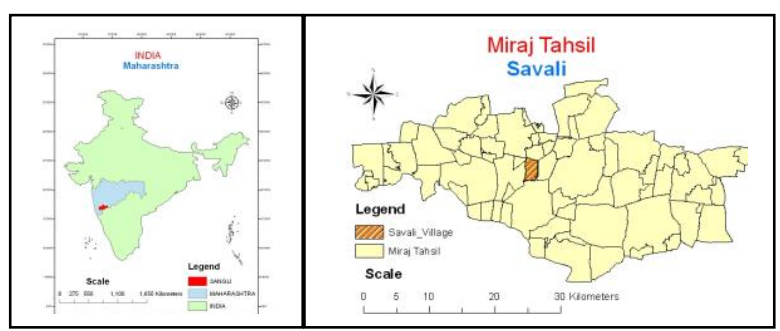




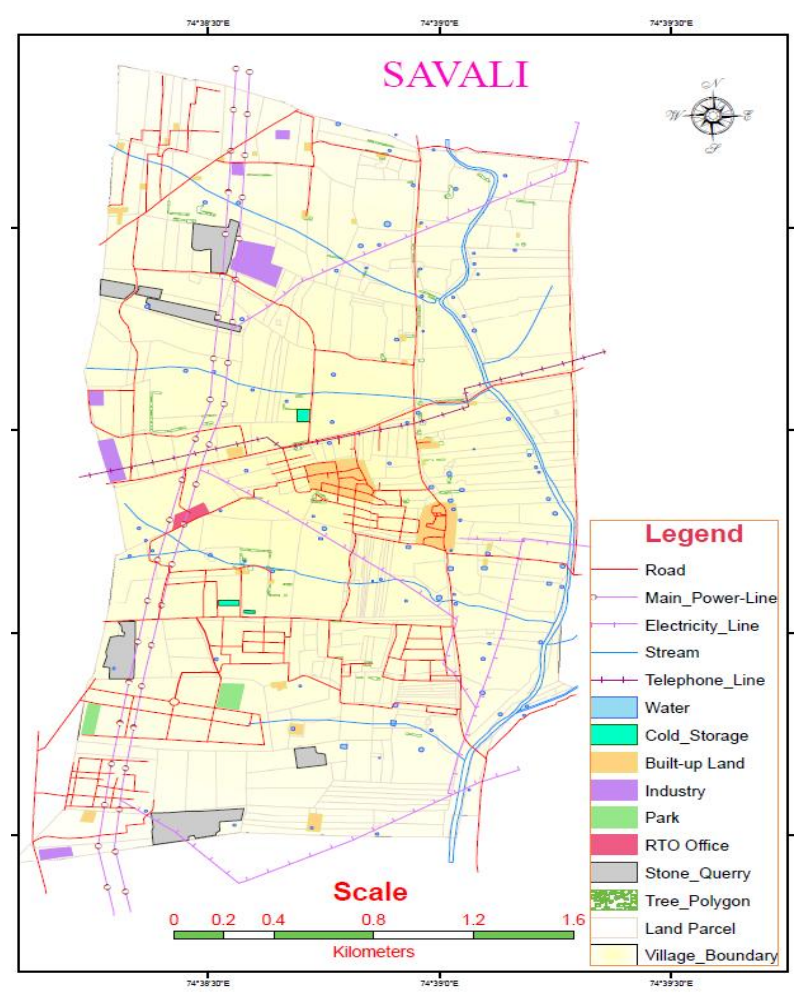

Fig 1: Location Map of Study Area

\section{DATABASE AND METHODOLOGY}

In this study both primary as well as secondary data is utilized but more focus was paid on primary data.

\subsection{Primary Data}

The primary data is collected through intensive field survey. The agricultural landuse survey is conducted to collect crop data. Along with agriculture landuse survey the soil and water survey is also conducted for mapping soil types in the village. The household survey is carried out and data is collected through questionnaire. The information about individual family, demographic structure, educational background, available facilities in village, the problems facing to the society, etc. are collected. GPS is used to collect the coordinates for cadastral map georeferencing and ground truth verifications. The informal interviews are conducted to get information about the impact of M.I.D.C. on the village and other eco-geographical factors.

\subsection{Secondary Data}

In this study various sources of secondary data are also used. The demographic data of the village is taken from the District Census Handbook. The data related to socio-economic is taken from the Statistical Abstracts. The study reports carried out by for B.A.-III students of Willingdon College, Sangli are also referred. The base mapping of survey land parcel is conducted by Cadastral map. The Survey of India Toposheet is used as a base map for creation of various data layers and information. Google earth high resolution satellite data is also used for individual household mapping. Other than that some other sources like telephone directory, updated election voters list, house ownership record, etc are used, these all are valid sources of information. The website http://164.100.111.5:8080/mahabhulekh/ is used to collect land records.
The methodology adopted for this study is quite simple and systematic. Initially the scope of work is decided then detail flow chart is prepared to classify data into proper categories. Once the volume of data is realized then database software is selected (MS-Access). As per the flow chart collected data is entered through forms. Then needed manipulation is carried out on added data. The Unicode option is applied for Marathi language. Some query analyses are performed to get desired results and at last derived results are represented through reports.

\subsection{DATABASE GENERATION}

In order to have a database to be truly functional, it must not only store large amounts of records, but be accessed easily. In addition, new information and changes should also be fairly easy to input. In order to have a highly efficient database system, it needs to incorporate a program that manages the queries and information stored on the system [6]. The advantages of database is having access to user, data security on the contrary it is having complex structure, time consuming to design, cost require for hardware and software are the major disadvantages. There are various types of database viz. Flat Model, Hierarchical, Network, Relational, etc. There are various types of databases are available like SQL, ORACLE, PostGrass, MS-Access, etc. The selection of database has to be done as per the need of project.

In this study MS-Access is used considering all aspects. Microsoft Access is a low cost relational database used mainly by home and small business users. It can run on a personal computer or server and provides an easy-to-use interface for designing simple databases, reports and data entry forms. It has good capabilities for connecting to other data sources and grab data from external databases.

Table 1. Database details of VIS

\begin{tabular}{|c|c|c|c|c|c|}
\hline Database & $\begin{array}{c}\text { Data } \\
\text { Set }\end{array}$ & $\begin{array}{c}\text { Data } \\
\text { Tables }\end{array}$ & $\begin{array}{c}\text { Records } \\
\text { Set }\end{array}$ & $\begin{array}{c}\text { English } \\
\text { Records }\end{array}$ & $\begin{array}{c}\text { Marathi } \\
\text { Records }\end{array}$ \\
\hline 1 & 2 & 18 & 5718 & 4728 & 990 \\
\hline
\end{tabular}

\section{RESULT AND DISCUSSION}

In this study all main components (tables, forms, reports, queries, etc.) of a MS Access database are used for VIS data.

\subsection{Tables}

The VIS contains different types of data which is collected from various sources. The agriculture information data set contains four main tables i.e. General Information, Ownership details, Other Rights and Crop details. The Household information contains three tables i.e. General Information, Family Particulars and Other Information. Other than these soil and water $\mathrm{pH}$, commercial places, industrial places, etc. tables are also created. These tables are functioning as attribute information which is further joined to shape files.

\subsection{Forms}

The data entries in the tables are made by two ways i.e. through Datasheet View or using Form. After data entry all records are checked properly and required manipulation is carried out to produce error free data. 


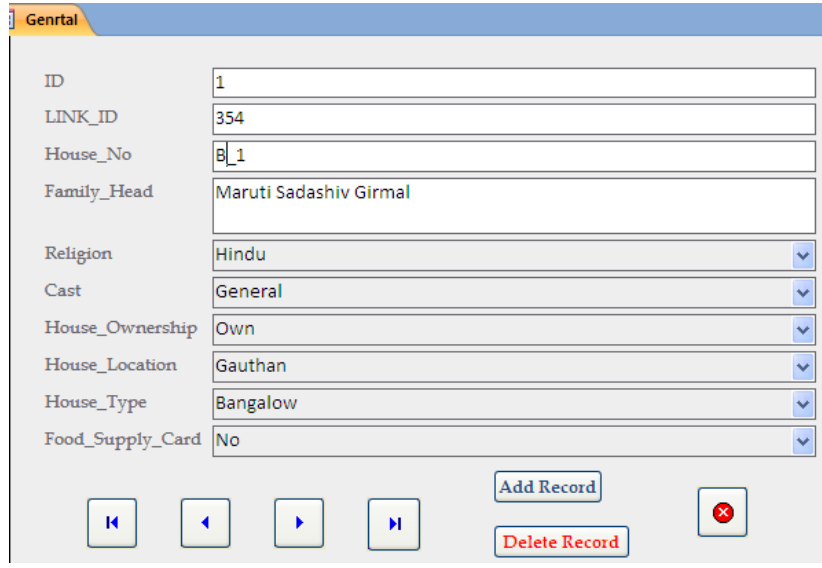

Fig 2: General Information Data Entry Form

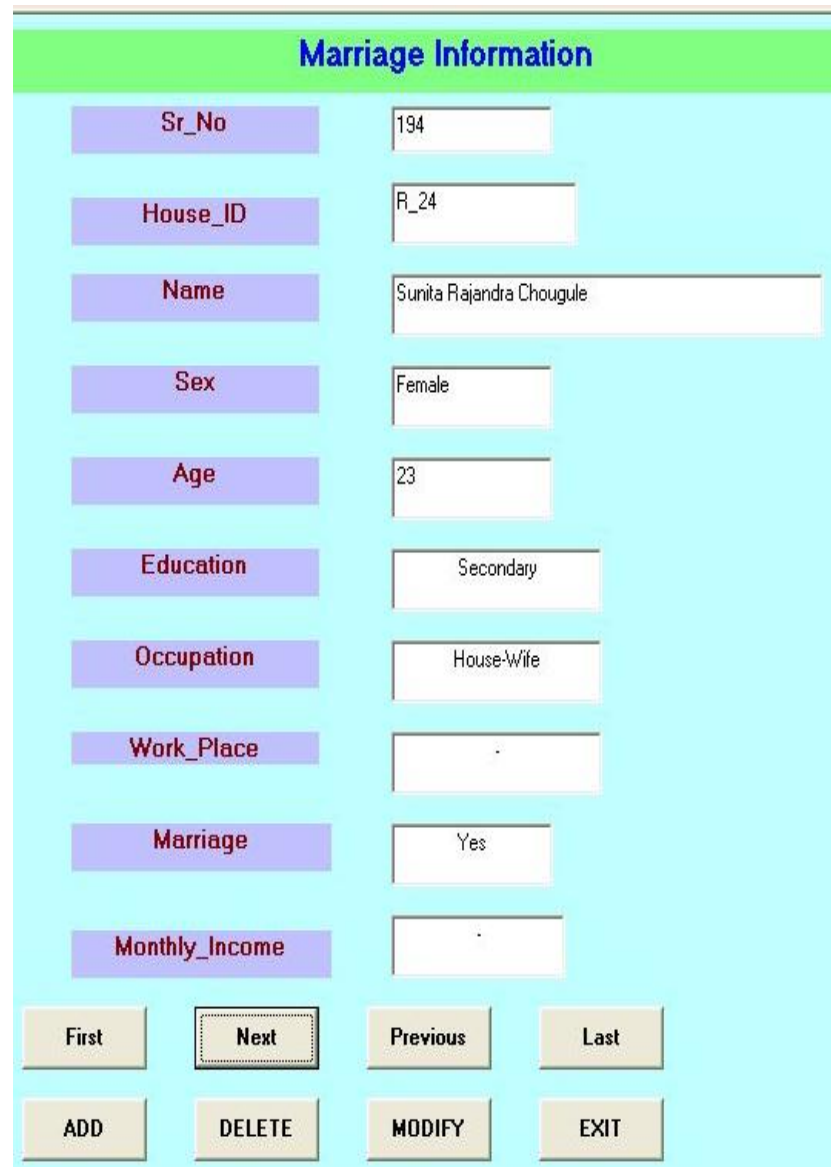

Fig 3: Marriage Information Data Entry Form

\subsection{Query}

Queries are great for getting information from a database. With a query, one can filter the data that stored in a table. The results appear in a tabular format in Datasheet view [8]. The query is most powerful tool of analysis but query has to be generated properly so that it will show the calculative as well as logical analysis (Fig.4).

\subsubsection{Query Output-(Irrigated Land Parcels)}

Fig. 5 is an output of a simple query, which is generated on General_Info table of Land-Record database. This query shows the information of irrigated land parcels in village, along with owner's name, record number, total as well as waste land, landuse, etc. Out of total 309 land parcels 25 parcels are having irrigation facility. It shows the percentage of irrigated land is quite low which affect the employment, economy as a result conversion into Non-Agriculture land is increased. The major stream 'Miraj Odha' is passing from Eastern side of village which is non-perennial and contains water only in rainy season. Entire agricultural land of this village is depends on well and tube wells. The proportion of irrigated land is very less hence, some measures like water shade management and water conservation needs to be implemented [7].

\subsubsection{Query Output - (Soyabeen Crop in Year 2003-04)}

Fig.6 is output of multiple query i.e. two record sets of a table, first is year and second is crop statistics. This query defines land parcel, year, season, crop, irrigated and un-irrigated land area, etc. Out of 884 records, 111 records are under Soyabeen and rest records are under other various crops. The below given snap shows Soyabeen is a non-irrigated crop but some places where irrigation facility is available there it is under irrigation. The database shows that Soyabeen is a major crop of Kharif season. Since Soyabeen is a cash crop and need not require much irrigation facility farmer prefers to cultivate this crop.

\subsubsection{Query Output - (Non-Agricultural Land Parcels in Village)}

Fig.7 is an output of a simple query which gives information about the Non-agriculture parcels in village. This village is adjacent to M.I.D.C. and on the edge of Municipal Corporation hence, some people invested money and purchased land parcels in this village for business purpose. New RTO office is situated in this village, considering this aspect many people are attracting towards village Savali. Shaha-Lulla estate developers have developed big portion of land in southern part of village this leads the growth of village wards Miraj. Due to various reasons several farmers sold their land and those patches are converted into Non-Agriculture plots. Fig. 7 shows the information about Non-Agricultural land parcels in the village, their survey numbers, Name of owner, plot area, etc.

\subsubsection{Query Output-(Ownership Rights of Land Parcel)}

Another important aspect of land parcel is ownership (Fig.8). There are three types of ownership of a land i.e. Main Owner, Common Owner and Other Owner. Snap shot Fig. 8 shows the ownership rights. Out of 1383 owners 377 are common owners and 86 are other owners. Most of the other owners are females because as per rule daughter is equally owner of the land in the family. 


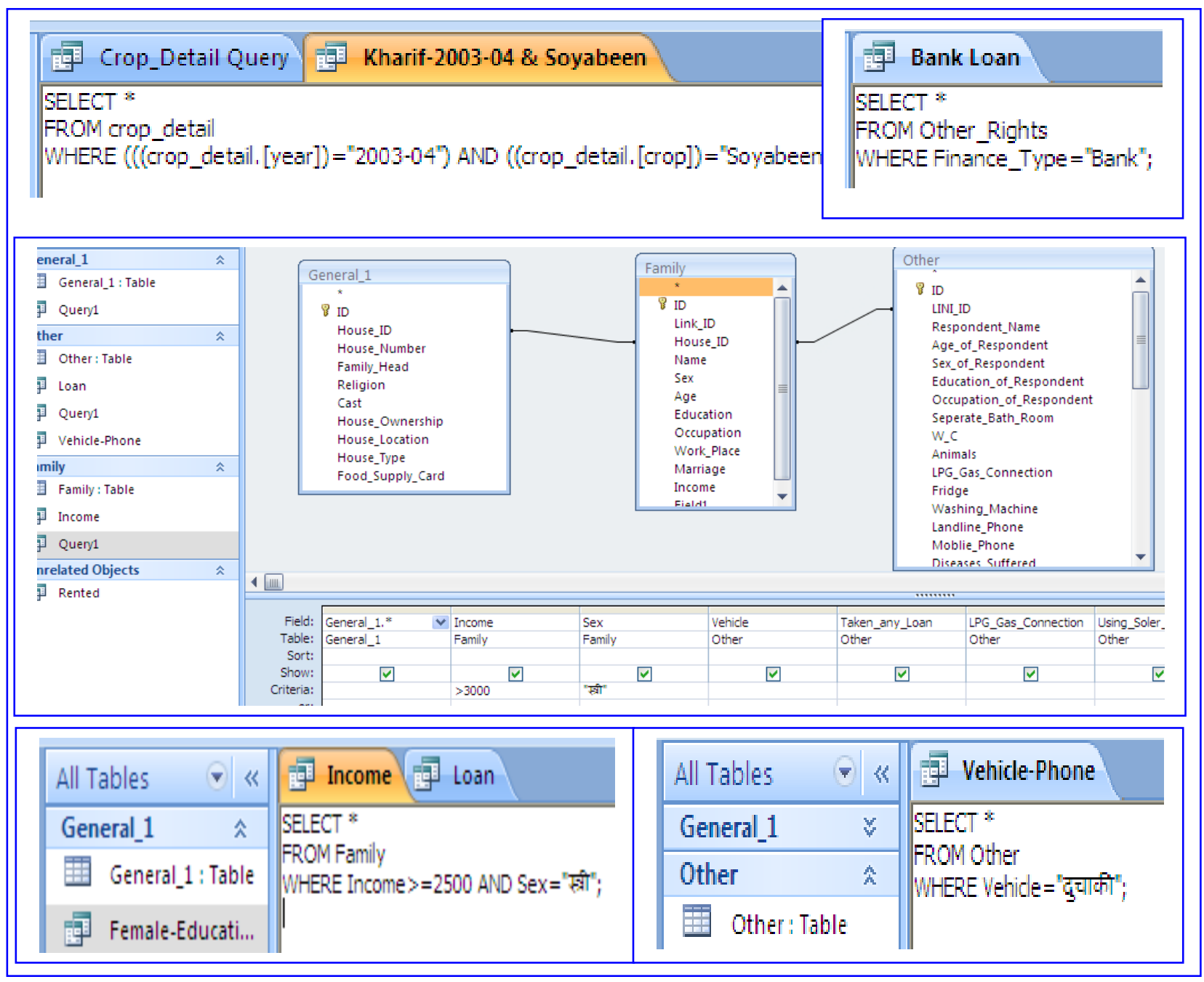

Fig 4: Query Formation and SQL Statement View

\begin{tabular}{|c|c|c|c|c|c|c|c|c|}
\hline \multicolumn{9}{|c|}{ Non-Agri Land Parcles } \\
\hline ID. LINK I $[$. & - Survey_. & Owner_Name & Common_Owne. & Other_Ownı. & Record_No & - Land_Type . & Waste_Lan . & Total_Land - Landuse \\
\hline 251244 & $227 / \mathrm{A}$ & Chaya Hanumant Nai & Yes & Yes & $439,440,441,442,4$ & 4. Irrigated & 0.06 & 2.03 Agriculture \\
\hline 252245 & $227 / \mathrm{b}$ & Ravindra Kalappa Khot & No & № & 706,736 & Irrigated & 0.05 & 2.03 Agriculture \\
\hline 254247 & 229 & Aappaso Aanappa khot & Yes & No & $16,107,539,634,63$ & 3! Irrigated & 0 & 1.98 Agriculture \\
\hline 255248 & 230 & Baban Bandu Mule & No & No & 597 & Irrigated & 0 & 1.87 Agriculture \\
\hline 256249 & 231 & Chairman Kanadwadi Vikas Co. Op Society & No & No & 766 & Irrigated & 0 & 0.27 Agriculture \\
\hline 257250 & 232 & Ibrahim Miraso Solapure & No & № & 628 & Irrigated & 0 & 0.29 Agriculture \\
\hline 258251 & 233 & Balaso Dhanpal Khot & Yes & № & $126,576,577,595,7$ & 7 (Irrigated & 0.02 & 0.25 Agriculture \\
\hline 259252 & 234 & Balaso Dhanpal Khot & Yes & Yes & $126,595,705$ & Irrigated & 0 & 0.6 Agriculture \\
\hline 260253 & 235 & Shrikant dada Khot & Yes & Yes & $4,126,595,596,770$ & 0 Irrigated & 0 & 5.1 Agriculture \\
\hline 261254 & 236 & Chairman Kanadwadi Vikas Co. Op Society & No & No & 766 & Irrigated & 0 & 0.25 Agriculture \\
\hline 262255 & 237 & Mahavir Aanappa Khot & No & No & 576 & Irrigated & 0 & 0.33 Agriculture \\
\hline 263256 & 238 & Balaso Dhanpal Khot & Yes & Yes & $126,595,705$ & Irrigated & 0 & 0.61 Agriculture \\
\hline 264257 & 239 & Bhupal Kalappa Khot & No & No & 1028 & Irrigated & 0.13 & 2.6 Agriculture \\
\hline 265258 & 240 & Sangali Zilla Bhu Vikas Bank & No & No & 761 & Irrigated & 0 & 1.67 Agriculture \\
\hline 266259 & 241 & Champabai Aanu Khot & Yes & Yes & $29,585,586,587,588$ & 8i Irrigated & 0.65 & 2.27 Agriculture \\
\hline 267260 & 242 & Shripal Nemu Khot & No & № & $2,708,709$ & Irrigated & 0.18 & 4.63 Agriculture \\
\hline 268261 & 243 & Ramesh Guraling Walvekar & Yes & № & $73,231,240,259$ & Irrigated & 0.01 & 0.03 Agriculture \\
\hline 269262 & 244 & Shobha Pandurang Kore & Yes & Yes & 154,165 & Irrigated & 0 & 0.86 Agriculture \\
\hline 270263 & 245 & Ramesh Guraling Walvekar & Yes & Yes & $73,231,240,259$, & Irrigated & 0 & 1.42 Agriculture \\
\hline 271264 & 246 & nnndiram Aananna Salu likhe & $\mathrm{Nn}$ & $\mathrm{Nn}$ & 132 & Irrinated & $n$ & $\cap 88$ Anrirulture \\
\hline
\end{tabular}

Fig 5: Irrigated Land Parcels in Village View 


\begin{tabular}{|c|c|c|c|c|c|c|c|c|c|c|}
\hline \multicolumn{11}{|c|}{ 7. Kharif-2003-04 \& Soyabeen } \\
\hline 4 & ID & . & LINK_LD & - Survey_No . & Year & - Season & Landuse . & Crop & Irrigated_Land . & Un-Irrigared_Land . \\
\hline & & 2 & & 21 & 2003-04 & Kharif & Three_Crop & Soyabeen & 0 & 1.15 \\
\hline & & 15 & & 152 & 2003-04 & Kharif & Four_Crop & Soyabeen & 0.9 & 0 \\
\hline & & 21 & & 213 & 2003-04 & Kharif & Single Crop & Soyabeen & 1.66 & 0 \\
\hline & & 25 & & 254 & 2003-04 & Kharif & Single Crop & Soyabeen & 1.56 & 0 \\
\hline & & 30 & & 305 & 2003-04 & Kharif & Three_Crop & Soyabeen & 0 & 1.11 \\
\hline & & 34 & & 345 & 2003-04 & Kharif & Three_Crop & Soyabeen & 0 & 1.11 \\
\hline & & 37 & & 376 & 2003-04 & Kharif & Double_Crop & Soyabeen & 0.6 & 0 \\
\hline & & 42 & & 428 & 2003-04 & Kharif & Single Crop & Soyabeen & 0 & 1.09 \\
\hline & & 45 & & 459 & 2003-04 & Kharif & Four_Crop & Soyabeen & 1.74 & 0 \\
\hline & & 56 & & 5611 & 2003-04 & Kharif & Single Crop & Soyabeen & 1.8 & 0 \\
\hline & & 62 & & 6212 & 2003-04 & Kharif & Single Crop & Soyabeen & 0 & 1.26 \\
\hline & & 66 & & 6613 & 2003-04 & Kharif & Single Crop & Soyabeen & 1.6 & 0 \\
\hline & & 71 & & 7114 & 2003-04 & Kharif & Single Crop & Soyabeen & 3.04 & 0 \\
\hline & & 83 & & 8316 & 2003-04 & Kharif & Single Crop & Soyabeen & 3.84 & 0 \\
\hline & & 90 & & 9017 & 2003-04 & Kharif & Double_Crop & Soyabeen & 0.79 & 0 \\
\hline & & 93 & & 9319 & 2003-04 & Kharif & Double_Crop & Soyabeen & 0.13 & 0 \\
\hline & & 97 & & 9720 & 2003-04 & Kharif & Single Crop & Soyabeen & 0.44 & 0 \\
\hline & & 100 & & 10021 & 2003-04 & Kharif & Single Crop & Soyabeen & 0.47 & 0 \\
\hline & & 103 & & 10323 & 2003-04 & Kharif & Sinqle Crop & Sovabeen & 0.27 & 0 \\
\hline
\end{tabular}

Fig 6: Soyabeen Crop in Year 2003 - 04

\begin{tabular}{|c|c|c|c|c|c|c|c|c|}
\hline \multicolumn{9}{|c|}{ 团 Non_Agri } \\
\hline & ID & Survey_No it & Sub/Survey/No न & Owner_Name & Landuse & Ferfar $\uparrow$ & Record_No † & Area. \\
\hline & 28 & 36 & $36 / 1 / A / 32$ & Rupali Prakash Raut & Non Agriculture & 3928 & 1946 & 232 \\
\hline & 29 & 36 & $36 / 1 / A / 33$ & Rachana Hement Raut & Non Agriculture & 3929 & 1947 & 297. \\
\hline & 30 & 36 & $36 / 1 / A / 34$ & Nitin Shantinath Arwade & Non Agriculture & 3051 & 1948 & 27 \\
\hline & 31 & 36 & $36 / 1 / A / 35$ & Ravindra Surchandra Shaha & Non Agriculture & 3051 & 1949 & 280 \\
\hline & 32 & 36 & $36 / 1 / A / 36$ & Sukumar Bapu Patil & Non Agriculture & 3051 & 1950 & 368.0 \\
\hline & 33 & 36 & $36 / 1 / A / 38$ & Narayan Natha Jadhav & Non Agriculture & 3051 & 1952 & 296.0 \\
\hline & 34 & 36 & $36 / 1 / A / 41$ & Bapu Prabhu Shinde & Non Agriculture & 3051 & 1955 & 295.0 \\
\hline & 35 & 36 & $36 / 1 / A / 42$ & Shivputra Annappa Arbole & Non Agriculture & 3051 & 1954 & 310.0 \\
\hline & 36 & 39 & $39 / 1$ & Kishor Ramvilas Kabra & Non Agriculture & 3971 & 1198 & 29 \\
\hline & 37 & 39 & $39 / 2$ & Amit Kishor Lulla & Non Agriculture & 3920 & 1199 & 308.0 \\
\hline & 38 & 39 & $39 / 3$ & Mahendra Ashok Tele & Non Agriculture & 3921 & 1200 & 308.0 \\
\hline & 39 & 39 & $39 / 4$ & Kishor Krushnadas Thakkar & Non Agriculture & 3466 & 1201 & 308.0 \\
\hline & 40 & 39 & $39 / 5$ & Sadashiv Mahadev Mali & Non Agriculture & 2762 & 1202 & 292.0 \\
\hline & 41 & 39 & $39 / 6$ & Mangla Kamlakar Patil & Non Agriculture & 2549 & 1203 & 31 \\
\hline & 42 & 39 & $39 / 8$ & Kamlakar Ramaonda Patil & Non Aariculture & 2547 & 1204 & 295.0 \\
\hline
\end{tabular}

Fig 7: Non-Agricultural Land Parcels in Village

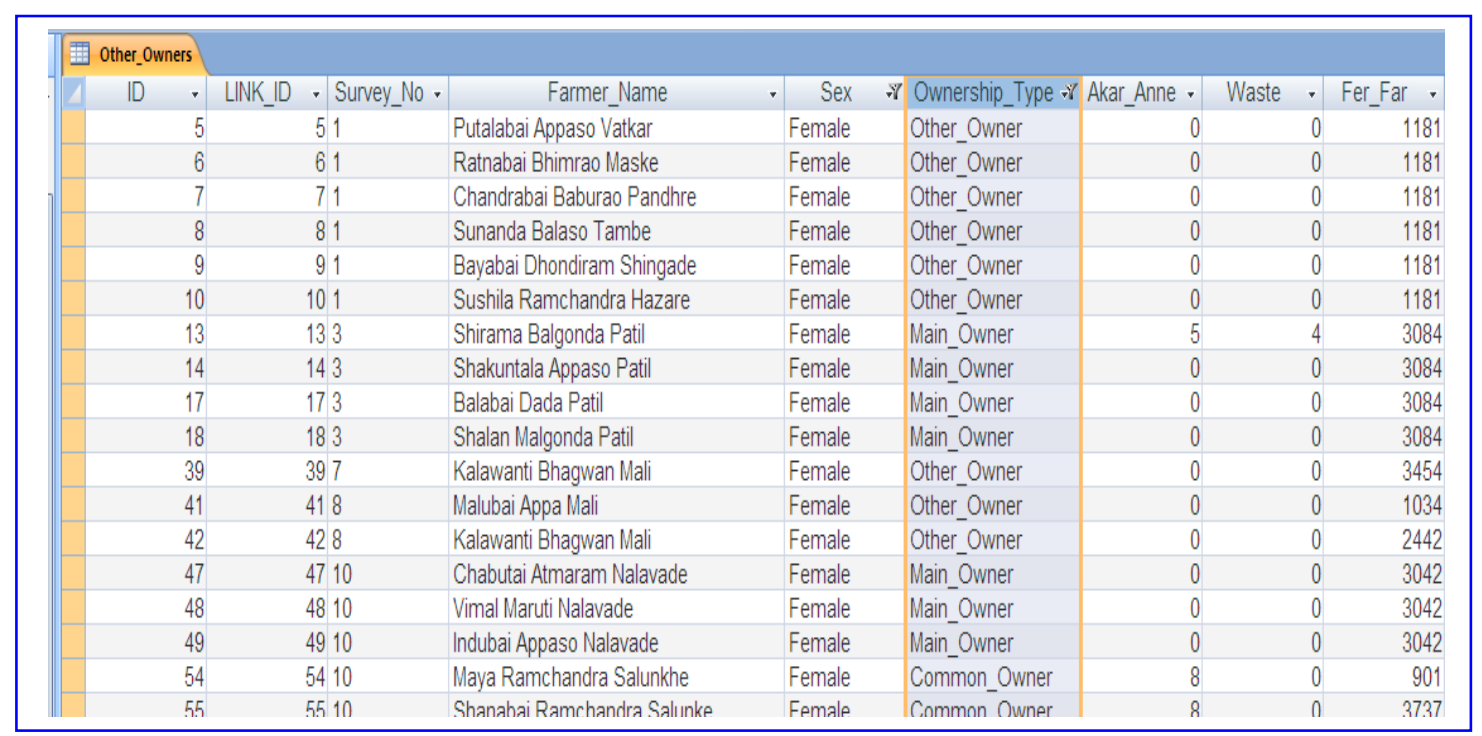

Fig 8: Other Ownership Rights of the Land Parcels in Village 


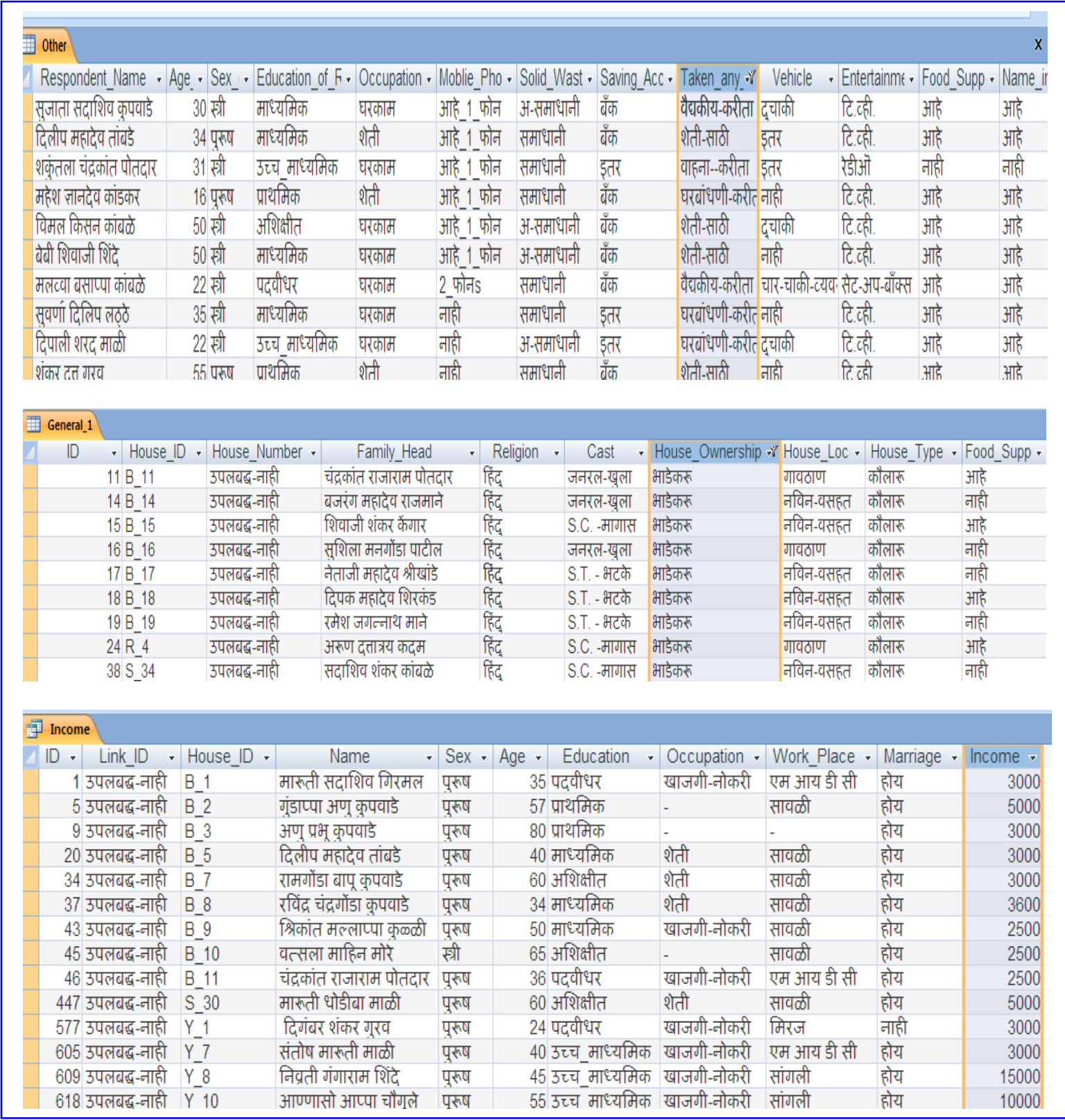

Fig 9: Query Output in Marathi

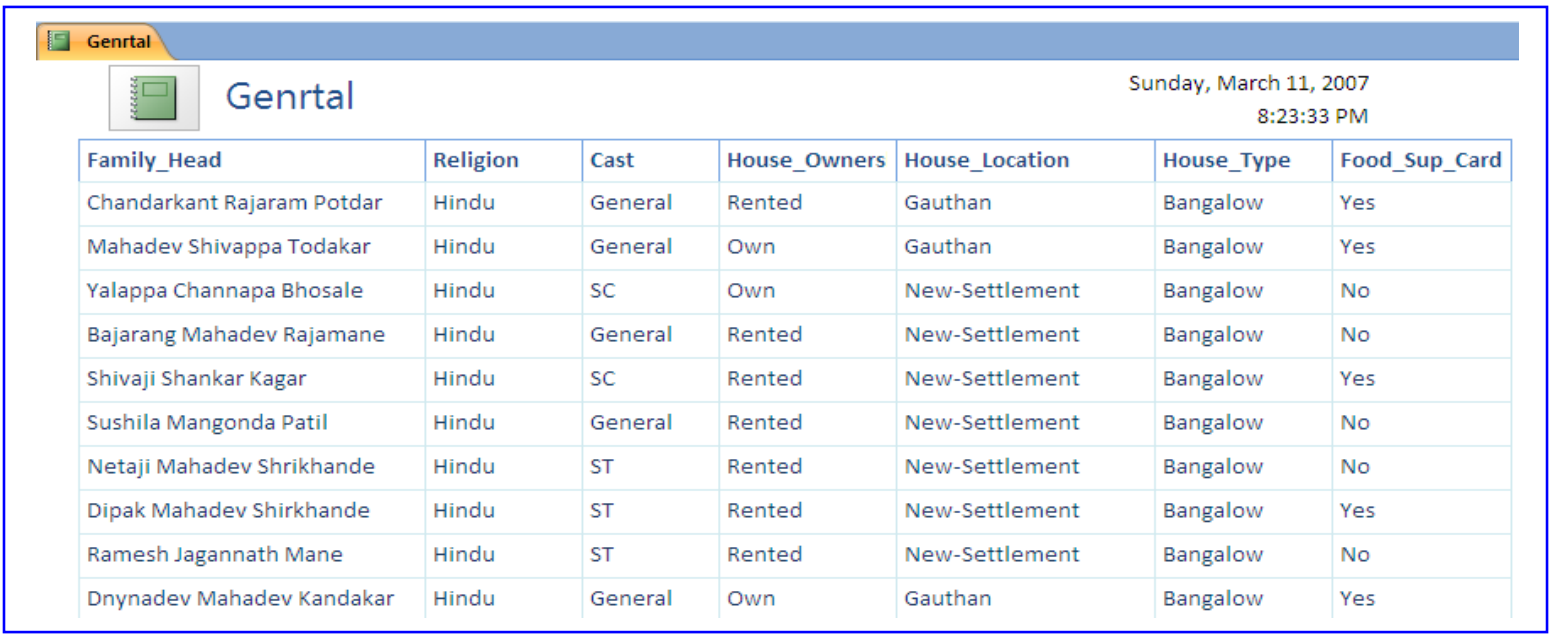

Fig 10: General View of Report 


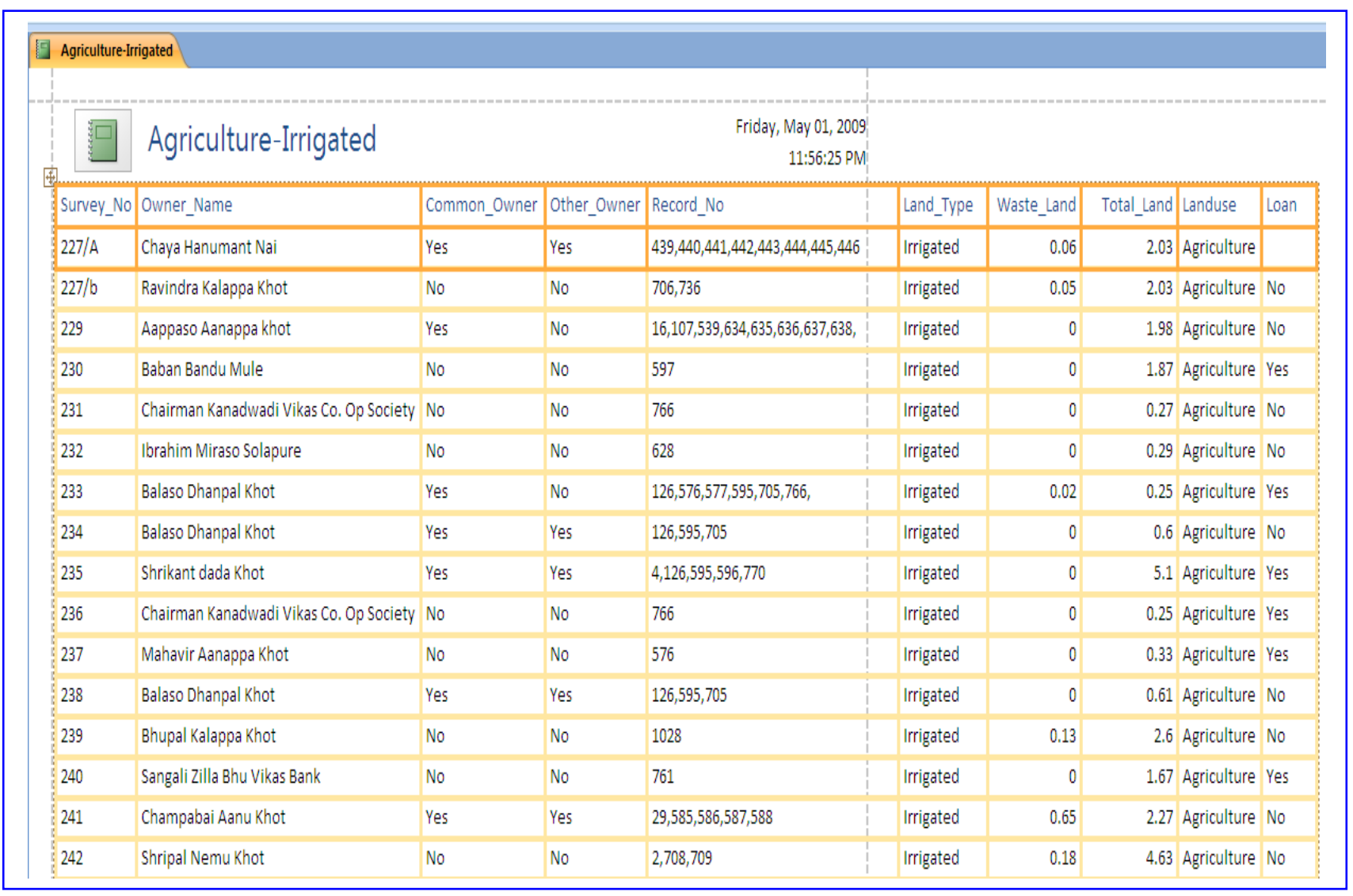

Fig 11: Agriculture Irrigated Land Parcels Report

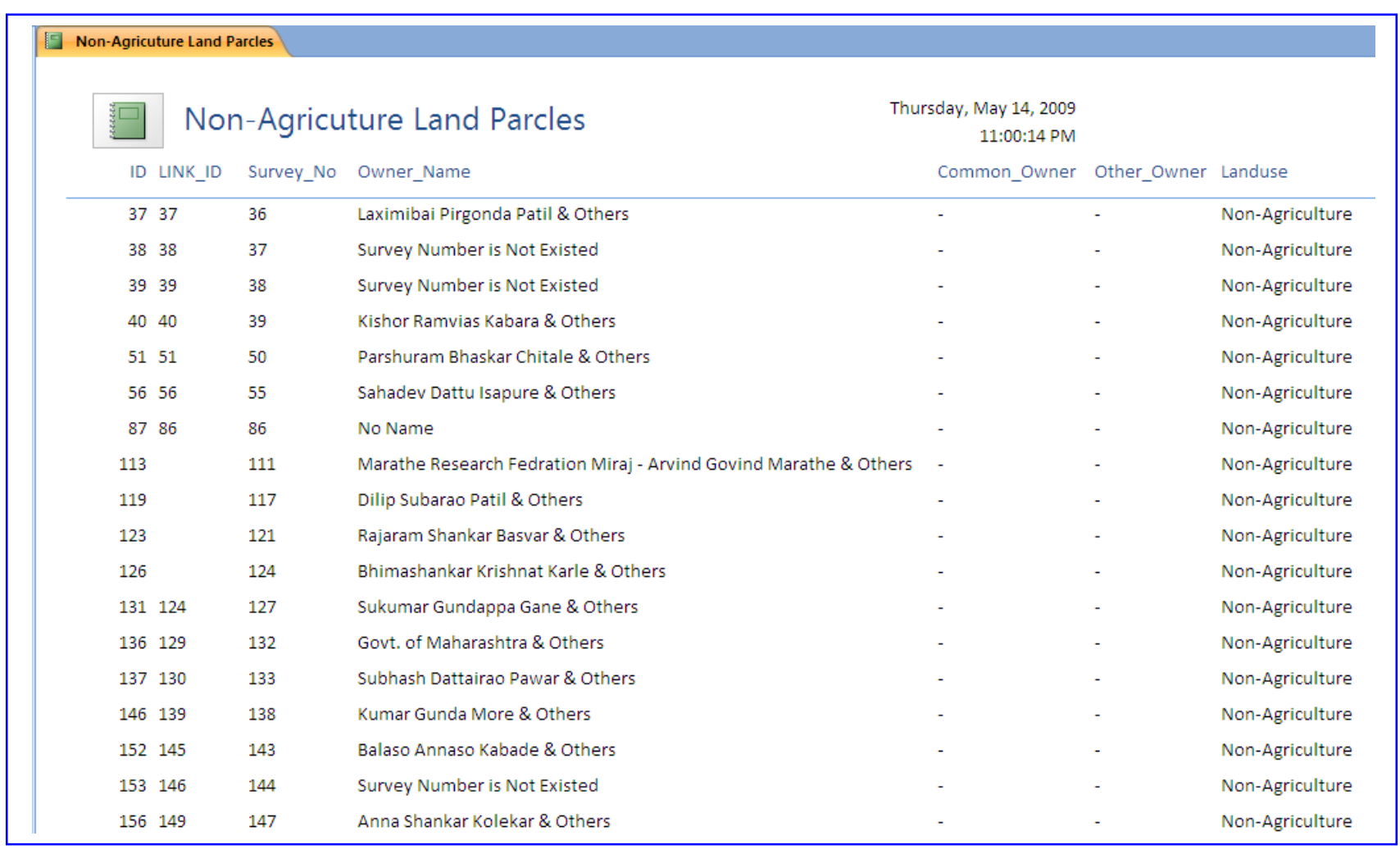

Fig 12: Non-Agriculture Land Parcels Report 


\subsubsection{Query Output -(in Marathi Language)}

Few queries are formed on Marathi database like how many two wheelers are available in village, income, tiles house, etc. (Fig.9) Each query shows the desired output in particular format like house number, name of head, their sex, age, education, etc. These queries are working as a means of filtering the needed information to the user. The snaps represented are some example of queries which generated for display purpose. The user can develop his own queries probably he must know how to generate a query using various parameters.

\subsection{Report}

A report is an effective way to present the data in a printed format. The user has control over the size and appearance of everything on a report. The reports can be generated for various aspects. The report is a fine medium of showing the information in organized format. It is having privilege to delete the unnecessary information and present required information in precise format. Few reports generated from the available data. Some generated reports are given below section Fig 10 is general information of household, Fig 11 is Agricultural-Irrigated land report and Fig 12 is about nonagricultural land parcels. The reports are very much useful for printing as well as soft copy view.

\section{CONCLUSION}

The generated database is multipurpose like it is centralized at one server, digital storage, helpful for government officials, further analysis by GIS users and many more. The spatial information about various features from village viz. land parcel, household, roads, water body, electricity line, telephone line, etc is made available with digital maps. The attribute information of these features i.e. Name of owner, land particulars, demographic details, crop information and many more is systematically stored in database.

The database created for VIS application is huge which contains 2 main datasets, 18 data-tables and 5718 record-sets out of this 4728 are in English and 990 in Marathi. The general table of Land Records contains 309 records of 11 informative columns. The Ownership table contains 1383 records of 7 data coloumns and the Crop detail table having 884 record sets in 8 coloumns. The database is also prepared for Non-Agriculture land parcels in the village which contains 506 record sets of 7 coloumns. Same way the database is developed for the Household information of village which contains 3 main tables. The general information table of Household having 176 record sets of 10 coloumns. The family information for same household is collected which is having 803 record sets along with this general satisfactory survey is conducted on same houses for 50 coloumns. The information given by these families are become very much useful during the analysis task. Same way the database is created in Marathi language which contains 990 record sets.

Various types of queries are generated on prepared database. These queries filter particular information and represent the desired output in systematic order for user. The details of Agriculture Land Parcels is processed and stored in a system. The system contains most useful information about land parcels like ownership, crop details, other rights on land, etc. Out of total 309 parcels, 63 parcels are having loan form
Bank, 110 from Co-operative society, 26 from Credit society. This statistics shows the use of land as a garniture in economic transactions.

The figures are well explanatory and represent the volume of database. The creation of structured database was a challenging work and selection of data type, data entry, data organization, data manipulation, etc. was time consuming as well as difficult task. To conclude it; the database generation for VIS is complicated and challenging task which can be handled efficiently by MS-Access. This task is accomplished systematically and properly so that it will be further helpful for VB application as well as for attribute data of shape files for spatial analysis.

\section{ACKNOWLEDGMENTS}

Special thanks to my teachers and research guides Dr. J. B. Chougule and Dr. K. C. Ramotra. Also thanks to villagers who cooperated during data collection and all who have contributed towards development of DBMS and VIS.

\section{REFERENCES}

[1] Saymote, P. A., Chougule, J. B. and Gaikwad, S. B. 2011. VIS (Village Information System): A Multipurpose Tool for Planning and Administration - A Case Study of Village Savali in Sangli District, Vol. 1 No.5, pp. 30 to 39 .

[2] Singh, H., Kewal K., and Litoria, P.K. 2009. Creation of a Village Information System of Moga district in Punjab using Geoinformatics. In proceeding of the National Conference on Recent Developments in Computing and its Applications, NCRDCA'09, August 12-13, 2009. Taken from http://www.researchgate.net/profile/Harpinder_Singh/pu blication/

[3] Lauesen, S. 2011. Microsoft-Access Tutorial. Taken from http://fisher.osu.edu/ muhanna.1/837/MSAccess/tutorial s.html

[4] Ravindran, A. and Jaishankar, J. 2008. GIS based Information System for Village Level Planning. GIS Development, Vol.8, Issue 2. pp. 9-10.

[5] Acharya, P. S. 2008. GIS based Technologies for Local Level Development Planning - An Overview. GIS Development, Vol.8, Issue 2. pp. 9-10.

[6] Mali, S., Bhailume, S. and Das, S. 2013. Geoinformatics Application for Urban Utilities Information System: A Case Study of Pune City, Maharashtra, India. International Journal of Computer Applications. Vol. 65, No. 22.

[7] Saymote, P. A., Jadhav, R. G. and Ghatage T. S. 2013. Use of AGPS in Geographical Studies, The Research View, Vol. 1 No.1.

[8] Sitender, Satish Kumar, and Reena. 2012. Village Information System - A Case Study of Muklan Village, Hisar, Haryana (INDIA). Published in International Journal of Research in Social Sciences, Vol. 2, Issue 2. Taken from http://www.ijmra.us 